Article

\title{
Future Changes in the Free Tropospheric Freezing Level and Rain-Snow Limit: The Case of Central Chile
}

\author{
Piero Mardones ${ }^{1,2,3, *(D)}$ and René D. Garreaud ${ }^{1,2}$ (D) \\ 1 Department of Geophysics, University of Chile, Santiago 8370415, Chile; rgarreau@dgf.uchile.cl \\ 2 Center for Climate and Resilience Research, University of Chile, Santiago 8370415, Chile \\ 3 Department of Oceanography, University of Concepción, Concepción 4030000, Chile \\ * Correspondence: pmardones@dgf.uchile.cl
}

Received: 14 October 2020; Accepted: 16 November 2020; Published: 23 November 2020

\begin{abstract}
The freezing level in the free troposphere often intercepts the terrain of the world's major mountain ranges, creating a rain-snow limit. In this work, we use the free tropospheric height of the $0{ }^{\circ} \mathrm{C}$ isotherm $\left(H_{0}\right)$ as a proxy of both levels and study its distribution along the western slope of the subtropical Andes $\left(30^{\circ}-38^{\circ} \mathrm{S}\right)$ in present climate and during the rest of the 21st century. This portion of the Andes corresponds to central Chile, a highly populated region where warm winter storms have produced devastating landslides and widespread flooding in the recent past. Our analysis is based on the frequency distribution of $H_{0}$ derived from radiosonde and surface observations, atmospheric reanalysis and climate simulations. The future projections primarily employ a scenario of heavy greenhouse gasses emissions (RCP8.5), but we also examine the more benign RCP4.5 scenario. The current $H_{0}$ distribution along the central Chile coast shows a gradual decrease southward, with mean heights close to $2600 \mathrm{~m}$ ASL (above sea level) at $30^{\circ} \mathrm{CS}$ to $2000 \mathrm{~m}$ ASL at $38^{\circ} \mathrm{S}$ for days with precipitation, about $800 \mathrm{~m}$ lower than during dry days. The mean value under wet conditions toward the end of the century (under RCP8.5) is close to, or higher than, the upper quartile of the $H_{0}$ distribution in the current climate. More worrisome, $H_{0}$ values that currently occur only $5 \%$ of the time will be exceeded in about a quarter of the rainy days by the end of the century. Under RCP8.5, even moderate daily precipitation can increase river flow to levels that are considered hazardous for central Chile.
\end{abstract}

Keywords: freezing level; climate change; central Chile; CMIP5; CFSR; flooding

\section{Introduction}

Most of the precipitation falling on the ground can be traced back to ice crystal formation in the subfreezing environment of the middle and upper troposphere when enough moisture is provided by tropical or extratropical weather systems [1]. As the ice crystals grow, they descend and eventually cross the $0{ }^{\circ} \mathrm{C}$ isotherm at a height $H_{0}$ above sea level (ASL) and begin to melt. The melting layer depth is highly variable, depending on the air temperature profile and the hydrometeors population (size, type, density), but it generally ranges between 100 and $300 \mathrm{~m} \mathrm{[2,3].} \mathrm{Over} \mathrm{the} \mathrm{terrain,} \mathrm{the} \mathrm{delimitation} \mathrm{of}$ sectors receiving rain or snow during a storm is also related to the position of the near surface $0{ }^{\circ} \mathrm{C}$ isotherm, although rain can occur with temperatures as cold as $-1.5^{\circ} \mathrm{C}$ and snow can occur with temperatures as high as $+1.5^{\circ} \mathrm{C}$ (e.g., $\left.[4,5]\right)$. The height of the $0{ }^{\circ} \mathrm{C}$ level over the terrain is closely tied to the nearby free tropospheric $0{ }^{\circ} \mathrm{C}$ isotherm height $\left(H_{0}\right)$ during precipitation events, but the surface level tends to be several hundred meters below its free tropospheric counterpart [6,7]. This offset is driven by the forced ascent of moisture-laden air parcels over the mountainous terrain that caused 
both adiabatic and diabatic cooling (the latter is due to the greater precipitation rates) as described in [6-8].

Although cloud microphysics and airflow-induced localized cooling can depress the elevation of the rain-snow limit over the terrain relative to the free tropospheric $H_{0}$ during a precipitation event, both heights are closely tied between storms (e.g., $[4,5,9,10])$. Furthermore, because the processes behind such offset are only weakly dependent on air temperature [7], the free tropospheric $H_{0}$ suffices to track the variability and change of the rain-snow limit over terrain in the large-scale climate change context addressed in this work.

Significant changes in the rain-snow limit elevation may occur in those regions where $H_{0}$ is close to the terrain at height $H_{G}$ (relative to sea level). Figure 1a shows the long-term mean distribution of the freezing level $\left(\overline{H_{0}}\right)$ when precipitation occurs, based on 32 years of reanalysis data (see details in Section 3). Despite the underlying continental distribution, the mean field is mostly symmetric in the zonal direction, with values above $4500 \mathrm{~m}$ ASL in the tropics and a gradual decrease down to $<500 \mathrm{~m}$ ASL poleward of $\sim 60^{\circ}$ in both hemispheres. The condition $H_{0}<H_{G}$, leading to snow as the dominant precipitation type, occurs at high latitudes but also over the world's major mountain ranges: the Tibetan Plateau, the Rocky Mountains, the Alps and the extratropical Andes. There, variations of the freezing level within precipitation events and between storms can produce substantial differences in the pluvial area — the expanse of terrain receiving rainfall—and runoff generation. Lundquist et al. [4] found that the coastal basins in the western United States of America are highly sensitive to $H_{0}$ because their pluvial area can change from $25 \%$ to $100 \%$ of the total area within the range of observed freezing level, thus modulating river flow during winter storms [11]. The freezing level control on surface runoff has also been noted in the Swiss Alps ([12] and reference therein). A similar condition occurs in the Andes cordillera, both in the Peruvian sector [13] and in central Chile [9] where high $H_{0}$ events can lead to destructive flash floods [14]. Liu et al. [15] described a catastrophic flooding event in Alberta (Canada) in which, among several factors, the high freezing level played a role not only by increasing the pluvial area but also because of the occurrence of rain-over-snow (ROS). ROS events are a serious hydrological threat most common at high latitudes in the Northern Hemisphere continents [16] but also in midlatitudes mountain areas (e.g., [4,17]).

Given the prospect of global warming during the rest of the 21st century, one may expect a widespread increase in the mean freezing level. Quantifying the impacts of climate change upon the distribution of $H_{0}$ thus informs us on potential shifts in the aforementioned hydrometeorological risks in mountainous regions (e.g., [18]) as well as changes in the water stored in the seasonal snowpack $[19,20]$. Changes in freezing level during precipitation events act in concert with those of precipitation intensity to alter the frequency distribution of runoff and river discharge, but, in a first approximation, they can be treated independently.

In this contribution, we use the tropospheric $H_{0}$ distribution to analyze projected changes of the freezing level and rain-snow limit changes over the western side of the subtropical Andes (central Chile). Occurrence of high-impact hydrometeorological events in this region is already high [21,22]; it is derived, at least partially, from high freezing level events [14]. To determine how specific our regional results are, we provide some large-scale context using global maps of selected variables. A brief climate context of the subtropical Andes is provided next in Section 2. The various datasets and methodology are presented in Section 3. Our main results are described in Sections $4.1\left(H_{0}\right.$ in the present climate) and Section 4.2 (projected changes under RCP8.5 and RCP4.5). Changes in the $H_{0}$ distribution have effects ranging from ecology (e.g., plant distribution) and hydrology (flooding and water availability) to tourism (e.g., snow-related activities) and mining (e.g., open-pit operations). Assessing those impacts is beyond the scope of this paper, requiring hydrological or earth-system modeling, but in Section 4.3, we include a brief discussion on, with simple estimates of, the projected changes in the occurrence of flooding and snowpack water storage, two of the most direct effects of the changing freezing level. Section 5 summarizes the key findings of this work. 

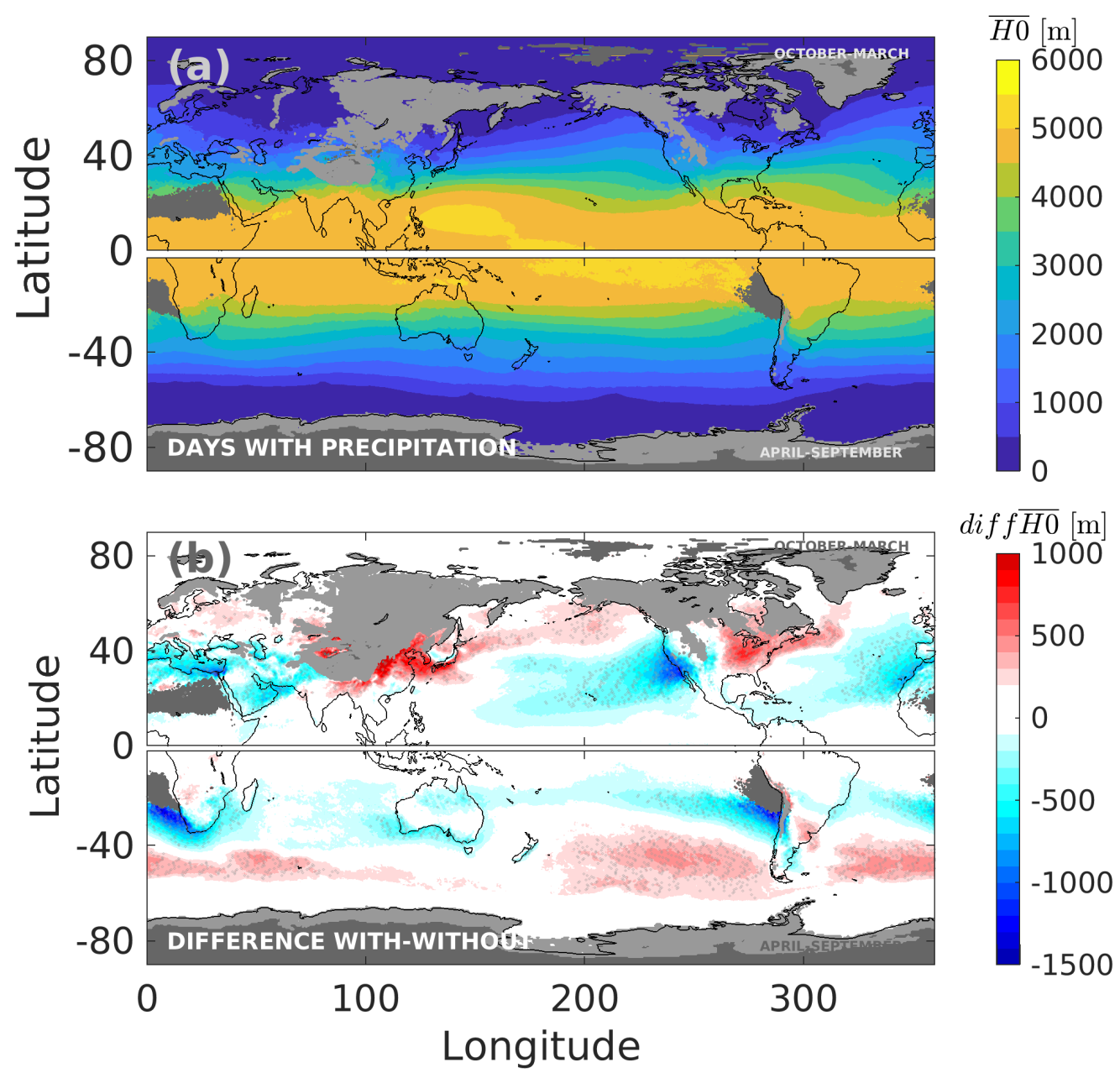

Figure 1. (a) Global distribution of mean $H_{0}$ (m above sea level (ASL)) calculated at any given grid box for days with precipitation ( $>5 \mathrm{~mm}$ /day in the grid box) during winter months (October-March for the Northern Hemisphere and April-September for the Southern Hemisphere). Data from the Climate Forecast System Reanalysis (CFSR) (see details in Section 3). (b) Difference of the mean $H_{0}$ between days with and without precipitation. Light gray areas represent those regions where mean $H_{0}$ intersects the topography. Dark gray areas indicate arid regions where the low number of rainy days precludes a robust calculation of $H_{0}$ under wet conditions.

\section{Study Region}

The Andes cordillera runs close to the western side of South America from north of the equator $\left(10^{\circ} \mathrm{N}\right)$ down to Tierra del Fuego $\left(53^{\circ} \mathrm{S}\right)$. Along its subtropical portion $\left(30^{\circ}-38^{\circ} \mathrm{S}\right)$, its crest level reaches more than $5000 \mathrm{~m}$ ASL, well above the mean freezing level during winter storms $(\sim 2400 \mathrm{~m}$ ASL; see Figure 1a). Central Chile, the narrow strip of land to the west of the subtropical Andes, is home to more than 12 million inhabitants with a large concentration ( $>7$ million) in the metropolitan area of Santiago that sits right at the Andean foothills. Annual mean precipitation in this region varies between 200-2000 mm (Figure 2), depending on latitude and height [23].

Precipitation is largely concentrated in the austral winter (May-September) and is mostly caused by cold fronts [24]. The Andes cordillera enhances precipitation by a factor of 2-3 between the upstream lowlands and the upper part of the mountains [23]. Between 10 to 20 precipitation events occur every winter lasting 1-3 days, with storm accumulations that are highly correlated with the amount of water vapor impinging against the Andes [24]. Indeed, extreme events ( $>50 \mathrm{~mm}$ per day) occur when intense atmospheric rivers ahead of cold fronts make landfall in this region $[25,26]$. Major storms generally 
result in marked, sudden increases in the flow of the rivers descending from the Andes [27], leading to flooding in central Chile. These events are a significant threat in central Chile, damaging infrastructure and causing loss of lives with a recurrence of 5-10 years [28]. Although the magnitude of the flooding is primarily controlled by the amount of the precipitation falling over the region, the elevation of the freezing level during the storms modulates the hydrological response [9]. During winter storms, $\overline{H_{0}} \sim 2200 \mathrm{~m}$ ASL over the upper Maipo river basin (area: $5500 \mathrm{~km}^{2}$ ) east of Santiago, but some precipitation events feature an $H_{0}$ in excess of $3500 \mathrm{~m}$ ASL, tripling the pluvial area relative to mean conditions, and thus increasing the risk of hydrometeorological hazards [9]. This was the case in 3 May 1993 when a moderate precipitation event occurred under warm conditions ( $H_{0} \sim 4000 \mathrm{~m}$ ASL), resulting in multiple landslides and downstream flooding on the city of Santiago that caused more than 80 fatalities and major damage in public and private infrastructure $[14,29,30]$.

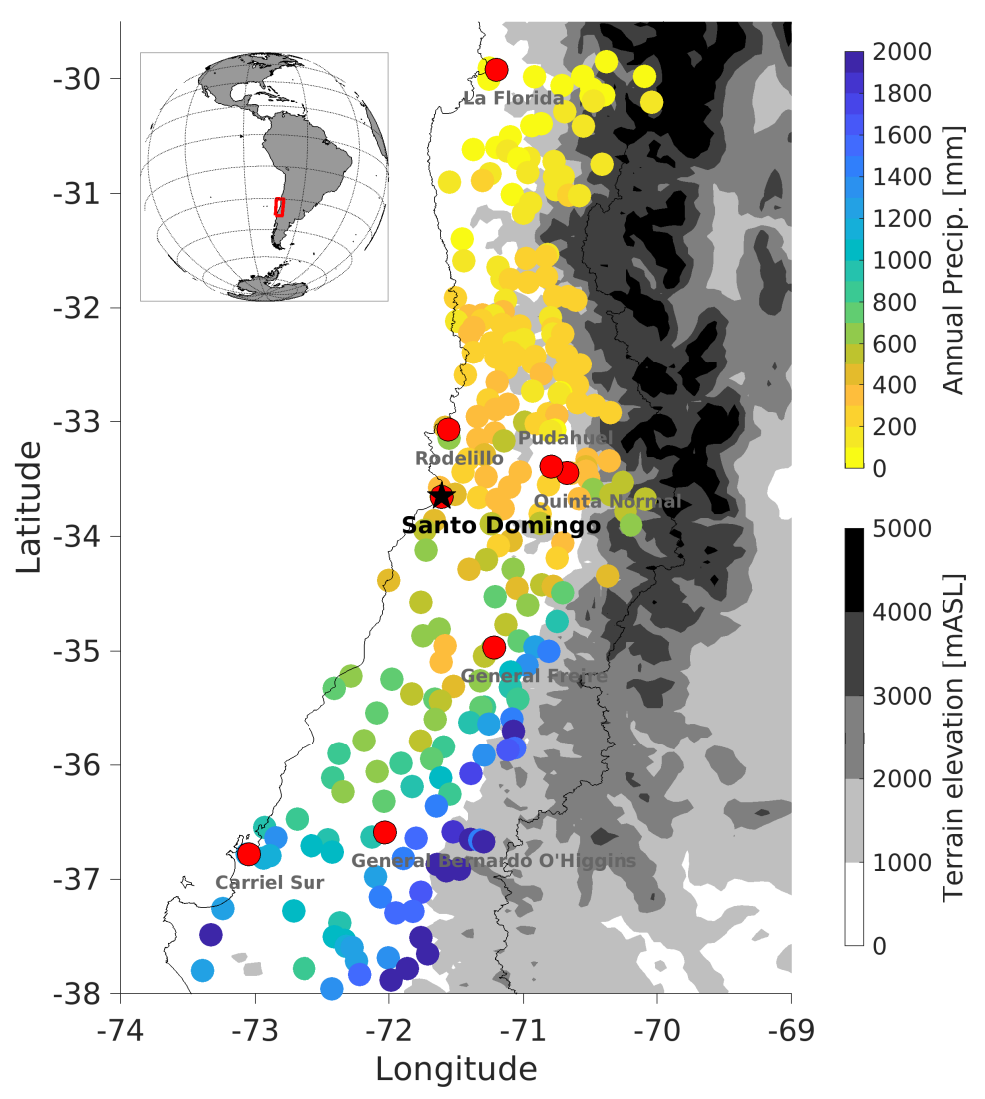

Figure 2. Station-based annual mean precipitation over Central Chile for the period 1981-2010, colored according to the scale to the right. Gray shading indicates topography levels from 0 to $5000 \mathrm{~m}$ ASL (every $1000 \mathrm{~m}$ ). The black star shows the location of the Santo Domingo upper air station and red circles show selected stations with concurrent air temperature and precipitation records used to infer the freezing level during rainy conditions.

\section{Data and Models}

\subsection{Observations}

Quality-controlled daily rainfall and average temperature is available from 1999 to 2017 for eight surface stations across central Chile $\left(30^{\circ}-38^{\circ} \mathrm{S}\right.$, Figure 2$)$ operated by the National Weather Service (DMC). In each station, we define a wet day as one with more than $5 \mathrm{~mm}$ accumulation and dry days as those with no precipitation. In this work, we only consider the winter semester (May to September) for central Chile and the rest of the Southern Hemisphere (SH). Santo Domingo, a coastal site at $33.65^{\circ} \mathrm{S}, 71.61^{\circ} \mathrm{W}(75 \mathrm{~m} \mathrm{ASL})$, is the only radiosonde station operated by DMC in this region 
(black start in Figure 2), with launches twice daily at 12:00 and 00:00 UTC. In all cases, there is only one level in which the air temperature profile crosses the $0{ }^{\circ} \mathrm{C}$, even if there is an inversion in dry days because they are warm and low [10], so the free tropospheric $H_{0}$ was obtained unambiguously from direct interpolation using the temperature and geopotential height of the levels just above and below $0{ }^{\circ} \mathrm{C}$. On a given day, a mean value of $H_{0}$ was calculated using the 00:00 UTC (8:00 PM of the previous day), 12:00 UTC (8:00 AM of the current day) and 00:00 UTC (8:00 PM of the current day) values, and then pooled into the wet or dry groups according to the concurrent rainfall data at Santo Domingo. In stations with surface data only (surface air temperature, SAT), we estimated the freezing level during rainy days using a moist adiabatic lapse rate $\left(\Gamma_{\text {moist }} \approx 6.5^{\circ} \mathrm{C} / \mathrm{km}\right)$ as $H_{0 s f c}=\mathrm{SAT} / \Gamma_{\text {moist }}+$ $H_{G}$, which proved to be a good approximation in this region [10,31]. In Section 4.3, the ETOPO2v2 elevation data [32] was used to determine hypsometric curves (basin area below a given height) of Andean selected basins in central Chile. Catchment boundaries are obtained from the CAMELS-CL dataset [33], where basin outlets are defined according to the location of available streamflow gauges and following topographic-driven limits.

\subsection{Reanalysis}

To supplement the reduced number of stations from where we can derive $H_{0}$ in central Chile and obtain a global perspective, we also employed the Climate Forecast System Reanalysis (CFSR, version 1) described in detail by Saha et al. [34]. Atmospheric variables from this state-of-the-art reanalysis system are available from 1979 to 2010 for every $6 \mathrm{hr}$ on a global $0.5^{\circ} \times 0.5^{\circ}$ lat-lon grid. As with the Santo Domingo sounding, the vertical profiles of air temperature and geopotential height were used to obtain $H_{0}$ in each grid point and time step. We then calculate the daily mean $H_{0}$ from the five values centered at 12:00 UTC (00:00, 06:00, 12:00, 18:00, 00:00 UTC) for every day. A comparison between observed $H_{0}$ at Santo Domingo and those obtained from CFSR is shown on Figure 3. There is a notable correspondence between daily averages of $H_{0}$ for both wet and dry days, with correlation coefficients exceeding 0.9. However, the relative error in the percentiles of the distribution does not exceed $3 \%$ in both cases. In Section 4.1, we provide further evidence that $H_{0}$ derived from CFSR is a good approximation of the actual $H_{0}$ distribution all along central Chile.

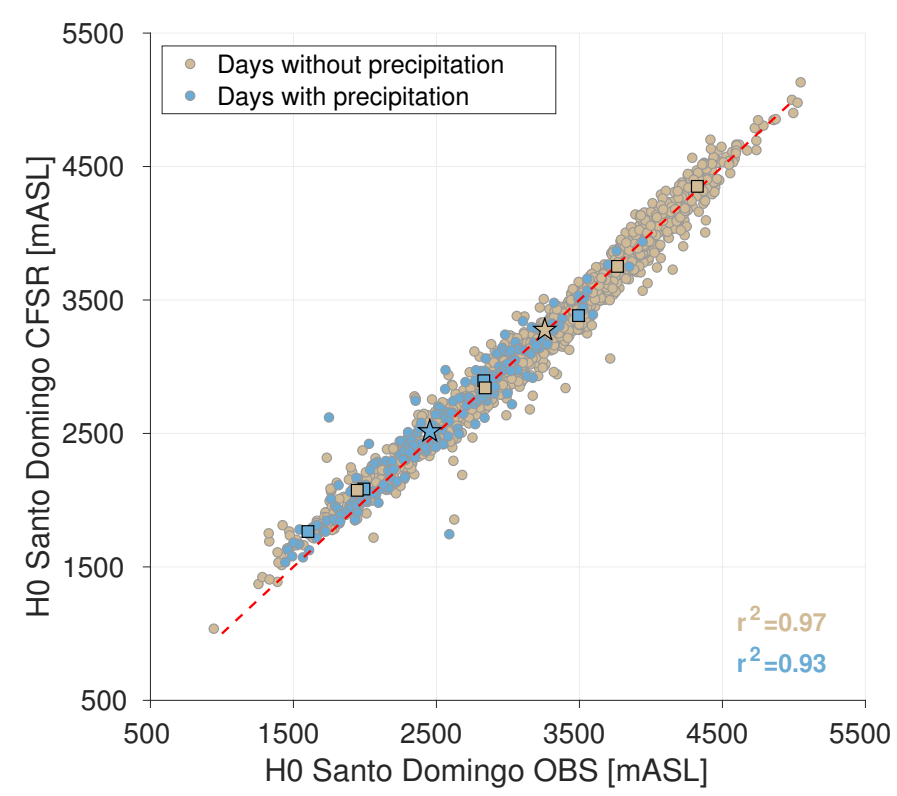

Figure 3. Scatter plot between daily mean values of $H_{0}$ observed in Santo Domingo $\left(33.65^{\circ} \mathrm{S}-71.61^{\circ} \mathrm{W}\right.$, sounding station) and $H_{0}$ from the closest grid point in the CFSR reanalysis $\left(33.50^{\circ} \mathrm{S}-71.50^{\circ} \mathrm{W}\right)$ for days with (blue dots) and without (brown dots) precipitation at Santo Domingo. Stars and squares represent the mean and percentiles (5th, 25th, 75th and 95th) for each distribution. The dashed red line is the 1:1 line. Data from 1999 to 2010. 


\subsection{Models}

To project the freezing level in the future, we use results from five models included in the Coupled Model Intercomparison Project Phase 5 (CMIP5, [35]) listed in Table 1. The variables used were daily averages of geopotential height, temperature (both at standard isobaric levels) and total precipitation at the surface. This allows us to obtain the daily freezing level grouped into wet and dry days at any given location for their respective winter season (May-September in the Southern Hemisphere and October-April in the Northern Hemisphere). Although the CMIP5 database includes results from more than 50 GCM, differing in their subgrid schemes (parameterizations) and spatial resolution, our analysis is restricted to those models with available surface and upper-air daily data and a grid spacing of $\sim 2^{\circ} \times 2^{\circ}$ (or finer) to obtain at least three grid points in latitude and a minimum representation of the Andes cordillera. The five selected models (from independent research centers) in the group conform to a good representation of the central Chile climate [36] and have resolution ranging from $0.75^{\circ}$ to $1.86^{\circ}$. Even so, the position of the coastline and Andes ridge of each model can differ substantially from their actual locations, so particular caution was taken in considering the topographic features of each model.

Table 1. Set of Coupled Model Intercomparison Project Phase 5 (CMIP5) models [35] used to characterize the future condition of the $H_{0}$ distribution. The variables $\mathrm{T}$ and $\mathrm{Z}$ correspond to temperature and geopotential height at isobaric levels. The variables pr and sftlf represent precipitation rate and fraction of land area, respectively.

\begin{tabular}{|c|c|c|c|c|c|}
\hline Model & Institution & Variables & $\begin{array}{l}\text { Spatial Resolution } \\
(\text { lat } \times \text { lon })\end{array}$ & $\begin{array}{l}\text { Isobaric Levels } \\
(\mathrm{hPa})\end{array}$ & Periods \\
\hline MPI-ESM-LR & $\begin{array}{l}\text { Max Planck Institute } \\
\text { for Meteorology, } \\
\text { Germany }\end{array}$ & $\mathrm{T}, \mathrm{Z}, \mathrm{pr}, \mathrm{sftlf}$ & $1.865^{\circ} \times 1.875^{\circ}$ & $\begin{array}{l}1000,850,700, \\
500,250,150, \\
100,70,50, \\
30,10,3, \\
1,0.3,0.1(15)\end{array}$ & \multirow{5}{*}{$\begin{array}{l}1976-2005 \text { (HIS) } \\
2011-2040 \text { (RCPs) } \\
2041-2070 \text { (RCPs) } \\
2071-2100 \text { (RCPs) }\end{array}$} \\
\hline MIROC5 & $\begin{array}{l}\text { Atmosphere and } \\
\text { Ocean Research } \\
\text { Institute (University } \\
\text { of Tokyo) }\end{array}$ & $\mathrm{T}, \mathrm{Z}, \mathrm{pr}$, sftlf & $1.400^{\circ} \times 1.406^{\circ}$ & $\begin{array}{l}1000,850,700, \\
500,250,100, \\
50,10(8)\end{array}$ & \\
\hline CNRM-CM5 & $\begin{array}{l}\text { National Center } \\
\text { of Meteorological } \\
\text { Research, France }\end{array}$ & $\mathrm{T}, \mathrm{Z}, \mathrm{pr}$, sftlf & $1.400^{\circ} \times 1.406^{\circ}$ & $\begin{array}{l}1000,850,700, \\
500,250,100, \\
50,10(8)\end{array}$ & \\
\hline MRI-CGCM3 & $\begin{array}{l}\text { Meteorological } \\
\text { Research } \\
\text { Institute, Japan }\end{array}$ & T, Z, pr, sftlf & $1.121^{\circ} \times 1.125^{\circ}$ & $\begin{array}{l}1000,850,700, \\
500,250,100, \\
50,10(8)\end{array}$ & \\
\hline CMCC-CM & $\begin{array}{l}\text { Centro } \\
\text { Euro-Mediterraneo } \\
\text { sui Cambiamenti } \\
\text { Climatici, Italy }\end{array}$ & $\mathrm{T}, \mathrm{Z}$, pr, sftlf & $0.748^{\circ} \times 0.750^{\circ}$ & $\begin{array}{l}1000,850,700, \\
500,250,100, \\
50,10(8)\end{array}$ & \\
\hline
\end{tabular}

The present climate distribution of $H_{0}$ considers the period between 1976 and 2005 from the historical runs. Based on the previous works [37], the CMCC-CM model has the least errors representing $H_{0}$ in central Chile in the present climate, being used as our reference model. For the rest of the 21st century, we use primarily the simulations under the RCP8.5 scenario [38], representing a negative prospect in terms of greenhouse gases emission and atmospheric concentrations [39] in which $\mathrm{CO}_{2}$-equivalent reaches about $1000 \mathrm{ppm}$ by the end of the century. In this sense, our work illustrates that changes that could occur in a worst-case scenario. Some key analysis, however, were repeated with climate simulations under the more benign RCP4.5 scenario $\left(\mathrm{CO}_{2}\right.$-equivalent $\sim 500 \mathrm{ppm}$ by 
the end of the century) to illustrate the sensitivity of the predicted changes in $H_{0}$ to the greenhouse gases concentrations.

\section{Results and Discussion}

\subsection{The Freezing Level in Present Climate}

Given the nearly two-dimensional nature of the Andes cordillera, extending almost straight north-south along its subtropical portion, and its proximity to the Pacific shoreline (Figure 2), most of the subsequent analyses are performed using the along-coast (latitudinal) profile of $H_{0}$. We acknowledge that the coastal, free tropospheric value of $H_{0}$ during a particular storm can differ from the actual snow line over the western slope of the Andes $[7,10]$ but any coast-to-Andes difference is likely to exist both in present and future climates, so it will not preclude exploring the climate change impact upon the freezing level.

Figure 4 shows the latitudinal variation of the mean freezing level $\left(\overline{H_{0}}\right)$ along the coast of central Chile using the CFSR values for wet and dry days during the winter semester (May-September). In the case of the wet days, we also included the surface-based $\overline{H_{0}}$ and the Santo Domingo $H_{0}$ distribution. There is a good agreement between the mean values derived from CSFR and the observations along the full transect, except for a $\sim 100 \mathrm{~m}$ offset in the mean value that was subsequently removed from the whole latitudinal profile. The mean freezing level during wet days $\left(\overline{H_{0}}\right.$ wet $)$ gradually decreases southward, from about $2600 \mathrm{~m}$ ASL at $30^{\circ} \mathrm{S}$ to $2000 \mathrm{~m}$ ASL at $38^{\circ} \mathrm{S}$. Except in the southernmost part of our study region, the mean freezing level is below the Andean crest, and at the latitude of Santiago and Santo Domingo $\left(33^{\circ} \mathrm{S}\right),{\overline{H_{0}}}_{\text {wet }} \sim 2400 \mathrm{~m} \mathrm{ASL}$, about half of the altitude of the mountain peaks that reach $\sim 6000 \mathrm{~m}$ ASL. The interquartile range of $H_{0}$ during wet days is close to $800 \mathrm{~m}$ all along central Chile, and extreme high values (95\% percentile) can reach up to $3500 \mathrm{~m} \mathrm{ASL}$, showing a high variability of the freezing level among winter storms, consistent with previous findings in Garreaud [9].

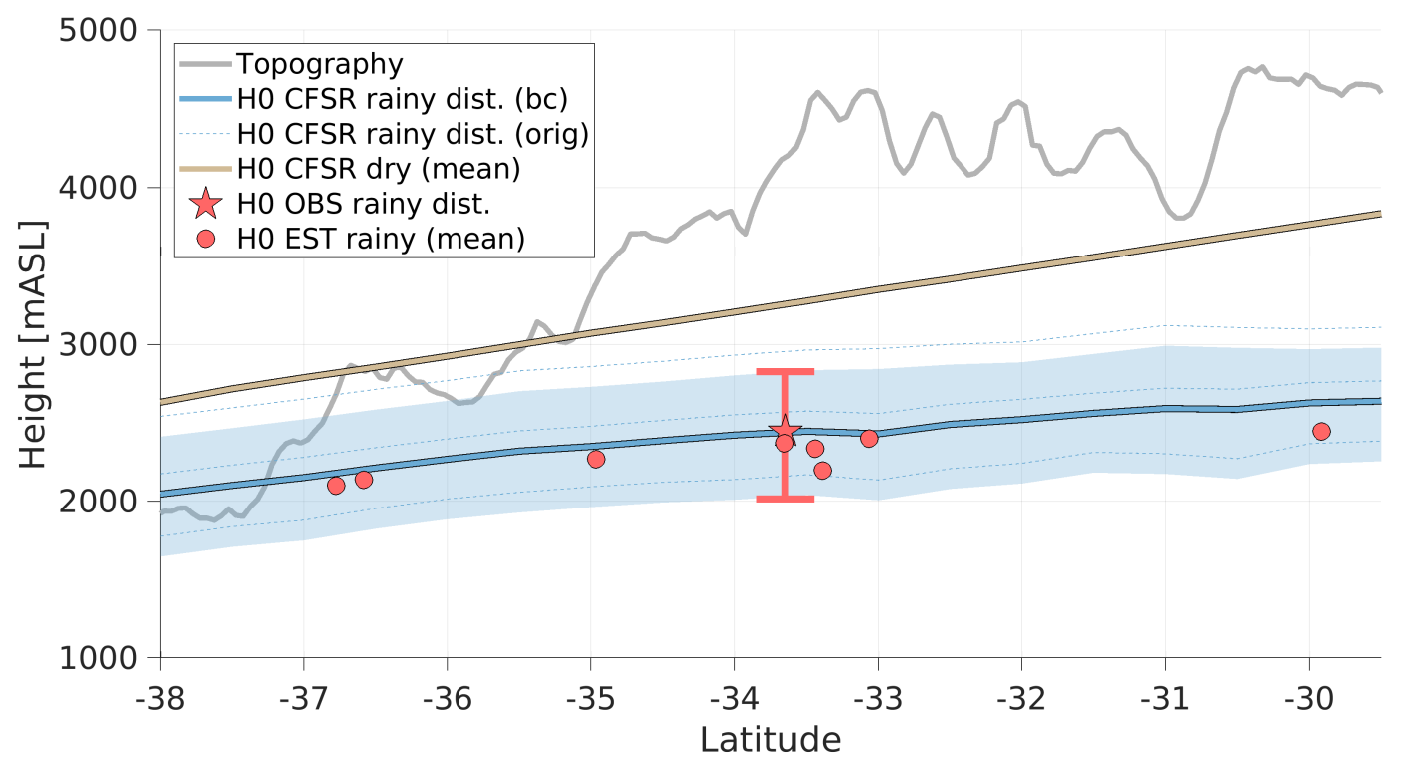

Figure 4. Latitudinal variation of the mean $H_{0}$ along the coast of Central Chile during days with (blue line) and without (brown line) precipitation, based on CFSR data. Blue shading indicates the interquartile range of $H_{0}$ during wet days. Gray line indicates the 97.5th percentile of terrain elevation, signaling the Andes crest level. Red dots are mean $H_{0}$ estimations based on surface data at selected National Weather Service (DMC) stations and the red whiskers indicate the interquartile range of $H_{0}$ using the observed values from the Santo Domingo soundings.

The mean freezing level for dry days during winter months (about $90 \%$ of the total) also decreases from north to south along the Chilean coast, and it is 800-1000 m higher than $\overline{H_{0}}$ wet. The standard 
deviation of $H_{0}$ under dry conditions is about $700 \mathrm{~m}$, so the freezing level distribution during rainy and dry days have little overlap (see Figure 3). Since both samples are obtained from the winter semester, the lower $H_{0}$ values during wet days reflect an actual drop of the air temperature in the lower and middle troposphere in connection with the postfrontal nature of precipitation in central Chile. There, the bulk of the precipitation falls in the first $12-24 \mathrm{~h}$ after the front passage cold front in the majority of the winter storms $[9,24,37]$. The $H_{0}$ depression during wet days-relative to dry conditions-also occurs near the west coast of other continents as evidenced in the reanalysis maps (Figure 1b) and documented over the Sierra Nevada in the United States of America [11] and the Iberian Peninsula [40]. Notably, $\overline{H_{0}}$ tends to rise during winter storms over the east side of the continents (most markedly in North America and East Asia) and the midlatitude oceans.

\subsection{Future Changes}

Let us begin our description of the future change in the freezing level by considering the frequency distribution of $H_{0}$ during winter wet days over Santo Domingo $\left(33^{\circ} \mathrm{S}\right)$ from the CMCC-CM model (Figure 5a). For present climate, the simulated $H_{0}$ distribution fits well with the observations in terms of the central value and spread. By the end of the century (2071-2100), under the RCP8.5 scenario, the shape of the distribution is preserved, but there is a substantial shift toward higher values $(\sim 600 \mathrm{~m}$ in the mean), consistent with the expected tropospheric warming. The shift in the $H_{0}$ distribution under the RCP4.5 scenario is similar to that in RCP8.5, but the increase in the mean value is about $\sim 400 \mathrm{~m}$. Figure $5 \mathrm{~b}$ synthesizes the north-south distribution of $H_{0}$ (mean value and interquartile range) during wet days for different decades in the 21st century, showing a progressive rise as time progresses. Note that toward the end of the century, $\bar{H}_{0 \text { wet }}$ is close to, or higher than, the upper quartile of the $H_{0}$ distribution in the current period, and the increase in $H_{0}$ seems to be slightly greater in the north. Near the southern limit of our domain $\left(37^{\circ}-38^{\circ} \mathrm{S}\right), \overline{H_{0}}$ wet in the current climate nearly coincides with the Andean ridge level, so the upper part of the mountains receive snow in about half of the winter storms, allowing the formation of a seasonal snowpack. By the end of the century, however, the mean freezing level during wet days is expected to be several hundred meters above the top of the southern Andes, so snowfall might be quite uncommon even over the highest terrain with a detrimental impact on water availability during the summer months [41]. The projected rise of $H_{0}$ toward the end of the century under the RCP4.5 scenario is about $70 \%$ of its RCP8.5 counterpart across the whole region.

To place changes throughout central Chile in a global context, Figure 6 shows the change in the mean freezing level $\left(\Delta \overline{H_{0}}\right)$ for wet days between the end of century (2071-2010, under RCP8.5) and the historical period (1976-2005) using the CMCC-CM model. There is an increase in $\overline{H_{0}}$ worldwide, most marked over the subtropical and tropical oceans $\left(\Delta \overline{H_{0}}\right.$ close to $1000 \mathrm{~m}$ ) but rather small at higher latitudes in both hemispheres. The pattern and magnitude of $\Delta \overline{H_{0}}$ is similar during dry days, but the projected rise tends to be $\sim 100-200 \mathrm{~m}$ higher across much of the subtropics and midlatitudes (not shown). In central Chile, for instance, $\Delta \overline{H_{0}}$ is close to $600 \mathrm{~m}$ ASL and $750 \mathrm{~m}$ ASL for wet and dry days, respectively.

Next, we examine the changes in freezing level in central Chile using results from the 5 GCM with high spatial resolution and daily data (Section 3.3). Except for CMCC-CM, the simulated $H_{0}$ distribution in current climate exhibits biases as large as $\pm 10 \%$ [37]; therefore, we use the so-called delta approach here to analyze future changes [42,43]. For each model, we calculate the future (end-of-the-century under RCP8.5) minus present difference in $H_{0}$ (mean value and selected percentiles), and then we average the five results. The multimodel mean $\Delta \overline{H_{0}}$ is then added to the observed (CFSR) profile of $\overline{H_{0}}$ in the current climate as shown in Figure $7 \mathrm{a}$ for the wet and dry winter day groups, along with an indication of the model spread. For the wet days, $\Delta \overline{H_{0}}$ is about $400 \mathrm{~m}$ (250-600 $\mathrm{m}$ range among the models), while for days without precipitation the mean change is close to $600 \mathrm{~m}$ (400-800 m range). The values of $\Delta \overline{H_{0}}$ have little variation along the profile. Similar increases were found when considering the median and the lower and upper quartiles, suggesting an overall shift of the $H_{0}$ frequency distribution while preserving its shape, as we showed for the specific case of 
CMCC-CM (Figure 5a). The latitudinal profiles of $\Delta \overline{H_{0}}$ for wet and dry days under the RCP4.5 scenario are also included in Figure 7a. When considering the multimodel mean, the rise in mean freezing level is about half of that obtained under RCP8.5, suggesting a linear behavior of the projected changes of the free tropospheric temperature in central Chile, in line with results from Zazulie et al. [44] for surface temperatures over the subtropical Andes.
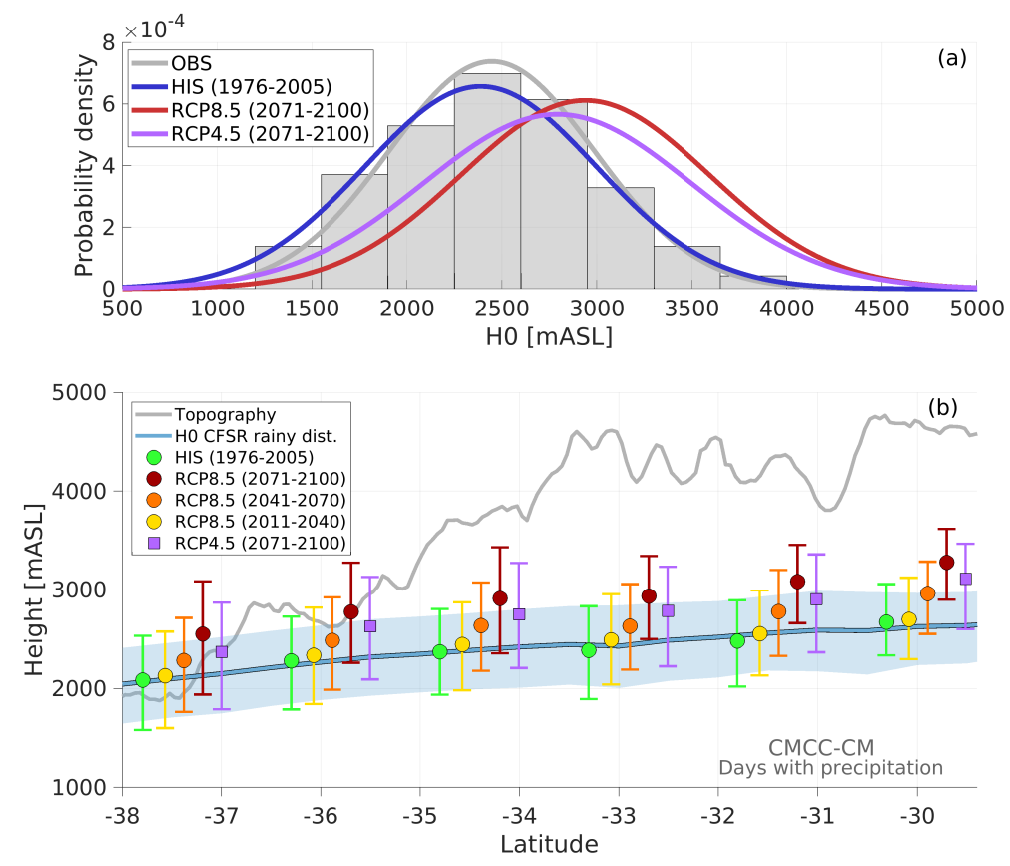

Figure 5. (a) The gray bars show the histogram of the observed $H_{0}$ at Santo Domingo during wet days and the gray line is the fitted normal distribution. The blue, red and purple lines are the fitted normal distribution of $H_{0}$ (during wet days) for present and future climate (2071-2100 under RCP8.5 and RCP4.5), respectively, simulated by the CMCC-CM model and interpolated to Santo Domingo. (b) Evolution of the CMCC-CM simulated $H_{0}$ distribution for days with precipitation, during different decades in the 21st century along the coast of central Chile. Circles indicate the mean of distribution and whiskers the upper and lower quartiles. The blue line and light blue shading are the present climate mean and interquartile range of $H_{0}$ (wet days) based on CFSR data. The gray line indicates the 97.5th percentile of terrain elevation.

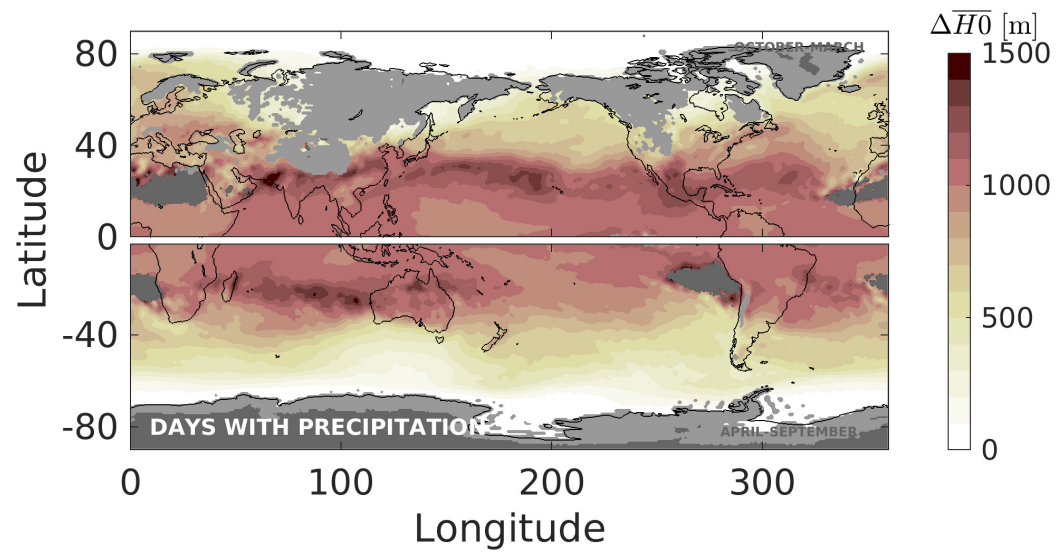

Figure 6. Global distribution of the difference in mean $H_{0}$ between the end of century (2071-2100 under scenario RCP8.5) and the historical period (1976-2005) simulated by the model CMCC-CM for winter days with precipitation. The winter months are October-March in the Northern Hemisphere and April-September in the Southern Hemisphere. Light gray areas represent those regions where mean $H_{0}$ intersects the topography. Dark gray areas indicate arid regions where the low number of rainy days precludes a robust calculation of $H_{0}$ under wet conditions. 
As noted in the introduction, winter storms with higher than average $H_{0}$ greatly increase the risk of flooding and landslides along central Chile, so particular attention must be placed in the change of extreme events. To gauge those changes, here we consider the variation in the $95 \%$ percentile value under wet conditions $\left(H_{095 \text { wet }}\right)$. At the latitude of Santiago, $H_{095 \text { wet }} \sim 3300 \mathrm{~m}$ ASL in the present climate, nearly $1 \mathrm{~km}$ above the mean value. For each model, we obtained $H_{095 \text { wet }}$ in the present-climate simulation, as a function of latitude, and then we calculated the frequency of the time in which this value will be surpassed in the last decades of the 21st century. The multimodel mean change in frequency is shown in Figure $7 \mathrm{~b}$. The mean frequency in which future freezing levels (during wet days) will equal or exceed the present climate $H_{095 w e t}$ is about $20 \%$ between $38^{\circ}-34^{\circ} \mathrm{S}$ and up to $30 \%$ in the northern part of the domain. Thus, what is now labeled as an extreme event will be a condition 4-6 times more frequent by the end of the century (under RCP8.5 scenario), a worrisome projection whose hydrological consequences will be discussed in the next section. Even in the case of the more benign RCP4.5 climate scenario, the frequency of extreme events ( $5 \%$ of the time in the current climate) could double (Figure $7 b$ ).
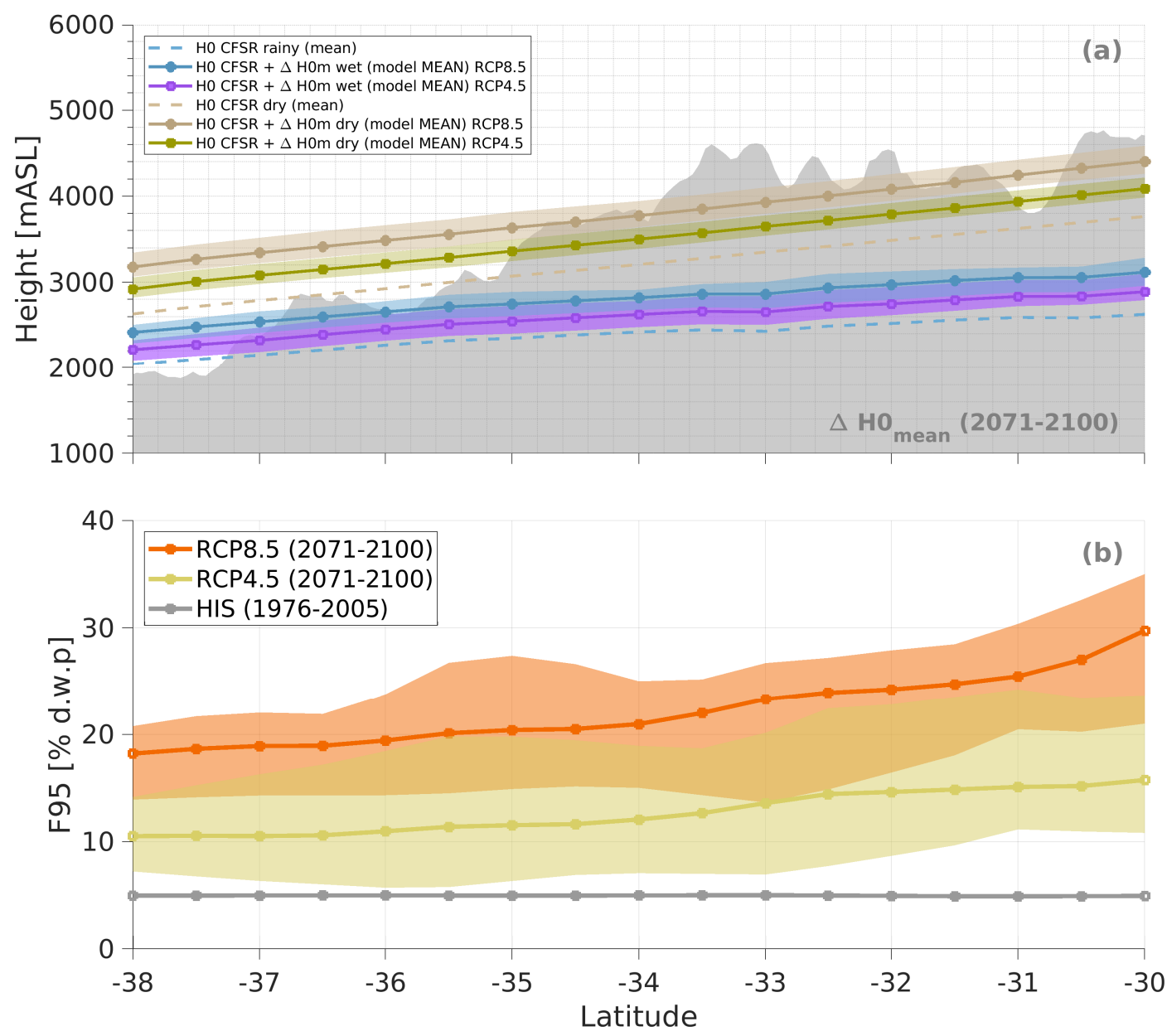

Figure 7. (a) Dashed lines indicate the profile of the mean $H_{0}$ along the coast of central Chile in present climate based on CFSR data for wet days (blue) and dry days (brown). The solid lines with circles are the multimodel mean $H_{0}$ for the end of 21st century under RCP8.5/RCP4.5 and the shading indicates the projection range (maximum-minimum). Gray shaded area indicate the 97.5 th percentile of terrain elevation. (b) End of the century (2071-2100) multimodel mean frequency of the 95th percentile $H_{0}$ value in the present climate. The line with circles and the shaded area represent the average and range (minimum and maximum) projected by the models. 


\subsection{Hydrological Impact}

Here, we provide a rough estimate of the hydrological impact of the $H_{0}$ changes during wet days over central Chile contingent of the occurrence of the RCP8.5 heavy emission scenario. Such impact varies with latitude since both $\bar{H}_{0 \text { wet }}$ and the terrain elevation decrease toward the south. Indeed, one may expect less acute impacts in the southern part of the domain because even in the current climate, the Andean basin mostly receives rainfall $\left(\overline{H_{0 w e t}} \sim H_{G}\right)$. Figure 8 a shows the area of the terrain above $1000 \mathrm{~m}$ ASL and below the present climate mean freezing level (during wet days) for selected Andean basins of central Chile $\left(A_{p}\right)$. The baseline was chosen close to the base of the Andes foothills. We then recalculated the $A_{p}$, keeping the baseline but changing the upper limit to $\bar{H}_{0 \text { wet }}$ in the future (2071-2100; RCP8.5) and $H_{095 \text { wet }}$ in the present and future climates. For selected basins, Figure 8b shows the areal increment factors, defined as the ratio of $A_{p}$ obtained with the new upper limits to the area defined with the present $\bar{H}_{0 \text { wet }}$. Considering the rise of the mean freezing level during winter storms, the most affected basins would those between $33^{\circ} \mathrm{S}$ and $35^{\circ} \mathrm{S}$. Particularly, the pluvial area in the upper Maipo River (that drains into the central valley just south of Santiago) almost doubles because of the projected rise in $\bar{H}_{0 \text { wet }}$ from present to future. Further south $A_{p}$ would be almost unaffected since most of the increase in $H_{0}$ occurs over the maximum height of the terrain. However, the basins north of $33^{\circ} \mathrm{S}$ would be less affected since their average slope is gentler. In present climate, the pluvial area also increases markedly when considering the $95 \%$ percentile $H_{0}$ relative to the mean value. Continuing our focus on the Maipo basin, we found that the pluvial area increases by a factor of 3 when considering the $95 \%$ percentile of $H_{0}$ in the present and by a factor of 4.5 when considering the $95 \%$ percentile events in the future. The increment factor in other basins is lower, but future warm storms might have a pluvial area 2-3 times larger than average storms in the present climate.
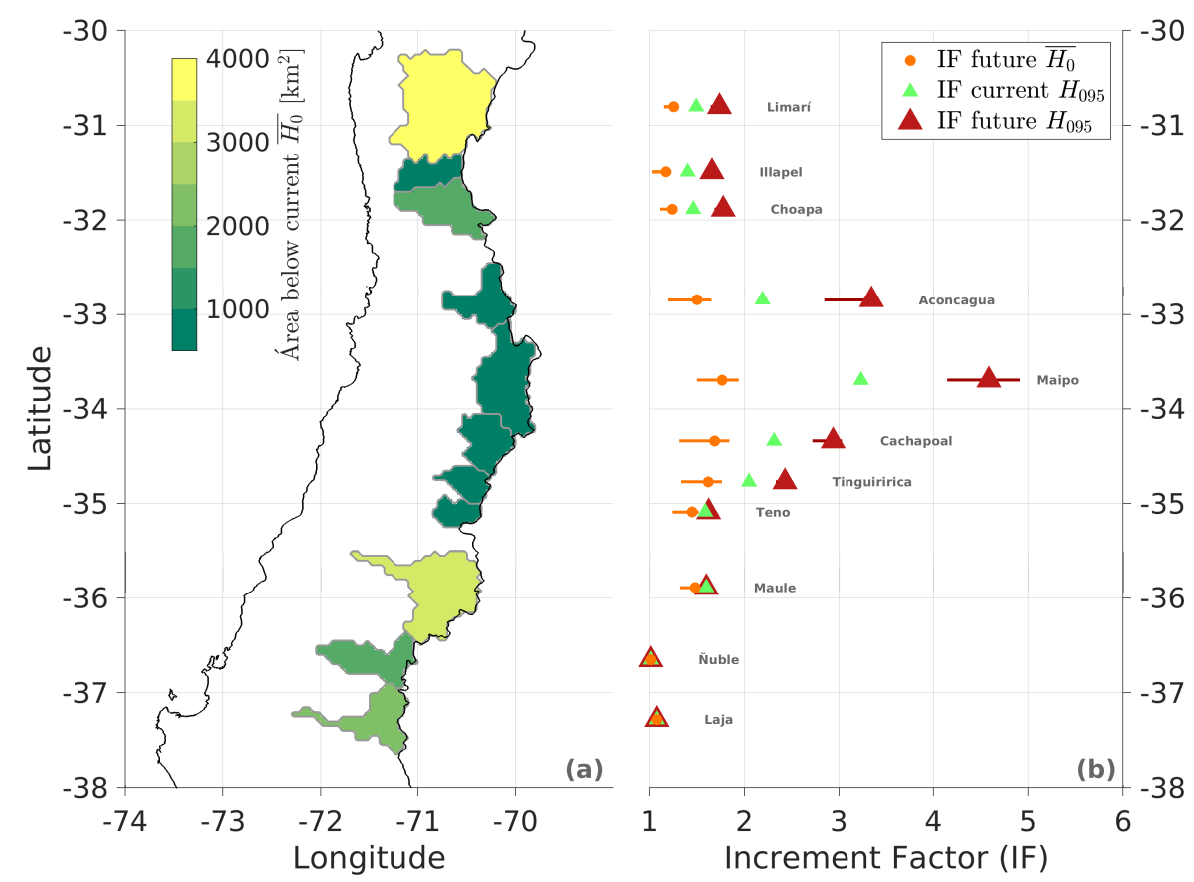

Figure 8. (a) Area between $1000 \mathrm{~m}$ ASL and below the mean of $H_{0}$ in current climate for selected basins in central Chile basins. (b) Increment factor of the area considering future $H_{0}$ values (mean and 95th percentile). See Section 4.3 for details. Lines in panel (b) indicate the range of models for each basin.

The large increase in the projected pluvial area for the Maipo basin, along with its closeness to the large city of Santiago, calls for further analysis. In Figure 9, we present contours of $H_{0}$ for mean and extreme cases under wet conditions, superimposed on a topographic map. Note, for instance, that nearly the entire basin would receive rainfall in the $5 \%$ of warmer winter storms of the future, 
a conditions that in the present climate has a probability of approximately less than $0.5 \%$. Of course, the river flow on a given storm is also dependent on the amount of precipitation and soil moisture (which dictate the infiltration rate), but an upper bound of the river flow can be easily obtained as $Q_{\max }=P B \times A_{p}$, where $P B$ is the basin averaged rainfall and $A_{p}$ depends directly from $H_{0}$ [24]. The right panel of Figure 9 shows $Q_{\max }$ as a function of the precipitation for selected values of $H_{0}$. We have marked the value $Q_{\max }=500 \mathrm{~m}^{3} / \mathrm{s}$, which is considered dangerous to this area based on the work of Bustos [45], and also include the frequency distribution of the daily precipitation for this basin.
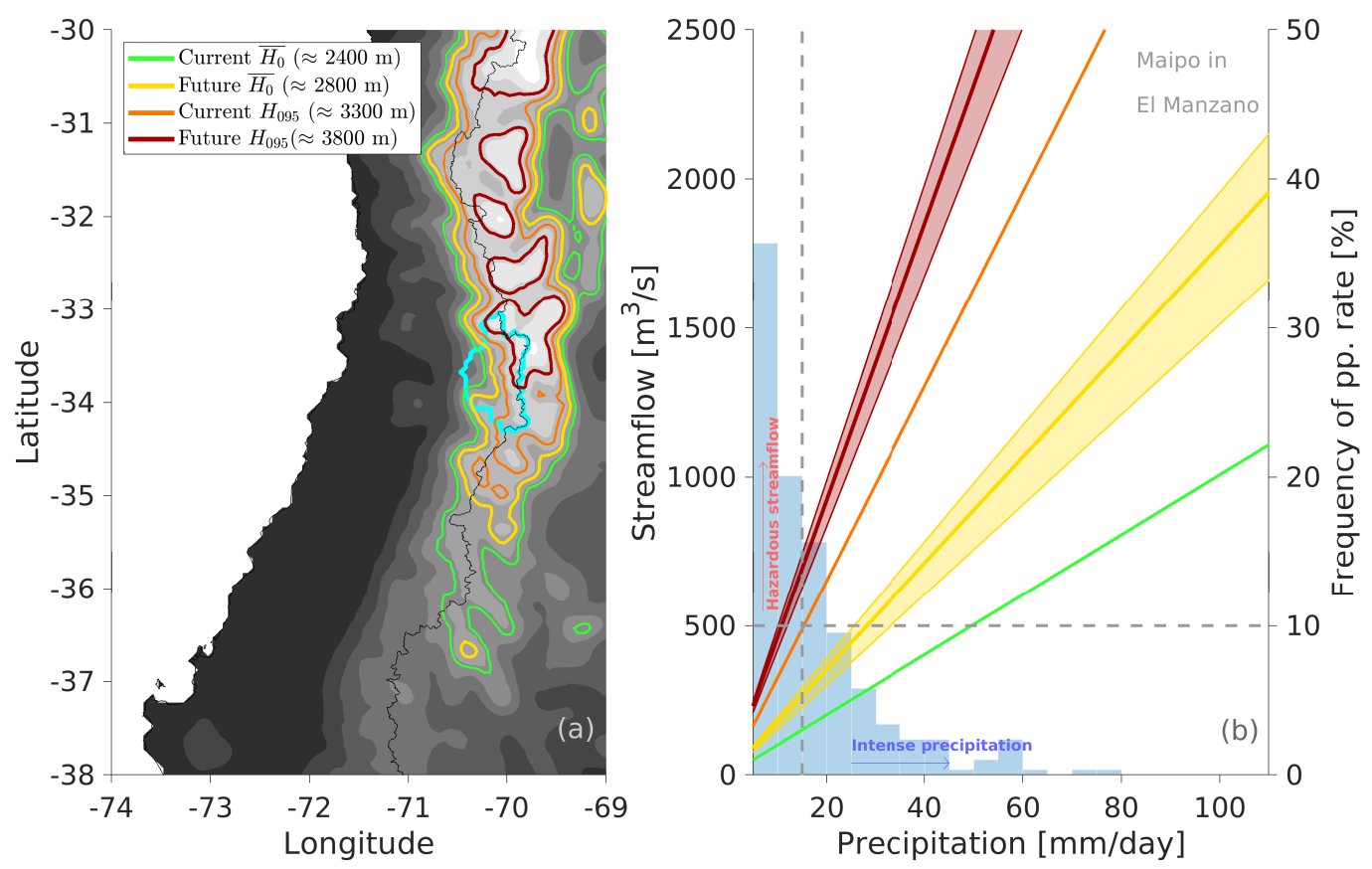

Figure 9. (a) Central Chile topography with present and future $H_{0}$ contours (mean and 95th percentile value). The upper Maipo river basin is delimited by the cyan line. (b) Estimated stream flow at the outlet of the upper Maipo river basin as a function of precipitation for different values of $H_{0}$ (mean and 95th percentile value) in present and end-of-the-century climate conditions (2071-2100 under RCP8.5). The histogram in the background shows the distribution of daily accumulated precipitation over $5 \mathrm{~mm}$ /day for station Quinta Normal in Santiago close to the outlet of the upper Maipo river basin.

For the mean freezing level in the present, at least $50 \mathrm{~mm} /$ day is required for the Maipo River to reach a dangerous level, a daily accumulation that happens in about $5 \%$ of the time (Figure $9 \mathrm{~b}$ ). In the future, however, flooding might be caused by a $25 \mathrm{~mm}$ /day storm, considering the mean freezing level, and by just $10 \mathrm{~mm} /$ day if the storm happens under warm conditions (95th percentile of $H_{0}$ ). This last value is even lower than the average daily accumulation, so such a hazardous combination of precipitation and freezing level leading to flooding may occur rather frequently despite the annual mean precipitation decrease over central Chile predicted for the rest of the 21st century by numerical models [46]. Indeed, projections based on the CMCC-CM model show that daily precipitation rate would change to lower values (Figure 10) and the number of wet days ( $\geq 5 \mathrm{~mm} /$ day) nearly halves from the current condition to the end of the century. Nonetheless, the number of days in which the combination of $H_{0}$ and precipitation results in a upper Maipo river flow $\geq 500 \mathrm{~m}^{3} / \mathrm{s}$ decreases marginally (from 107 to 92 days per 30 years), thus doubling the frequency in which hazardous condition occurs if precipitation is taking place. The increase in such conditional frequency is even more striking considering higher river flow values. For $Q_{\max } \geq 2000 \mathrm{~m}^{3} / \mathrm{s}$, not only does the conditional frequency triple but the total number of days increases toward the end of the century under the RCP8.5 scenario, considering the CMCC-CM model results and the simple hydrological model described before. 


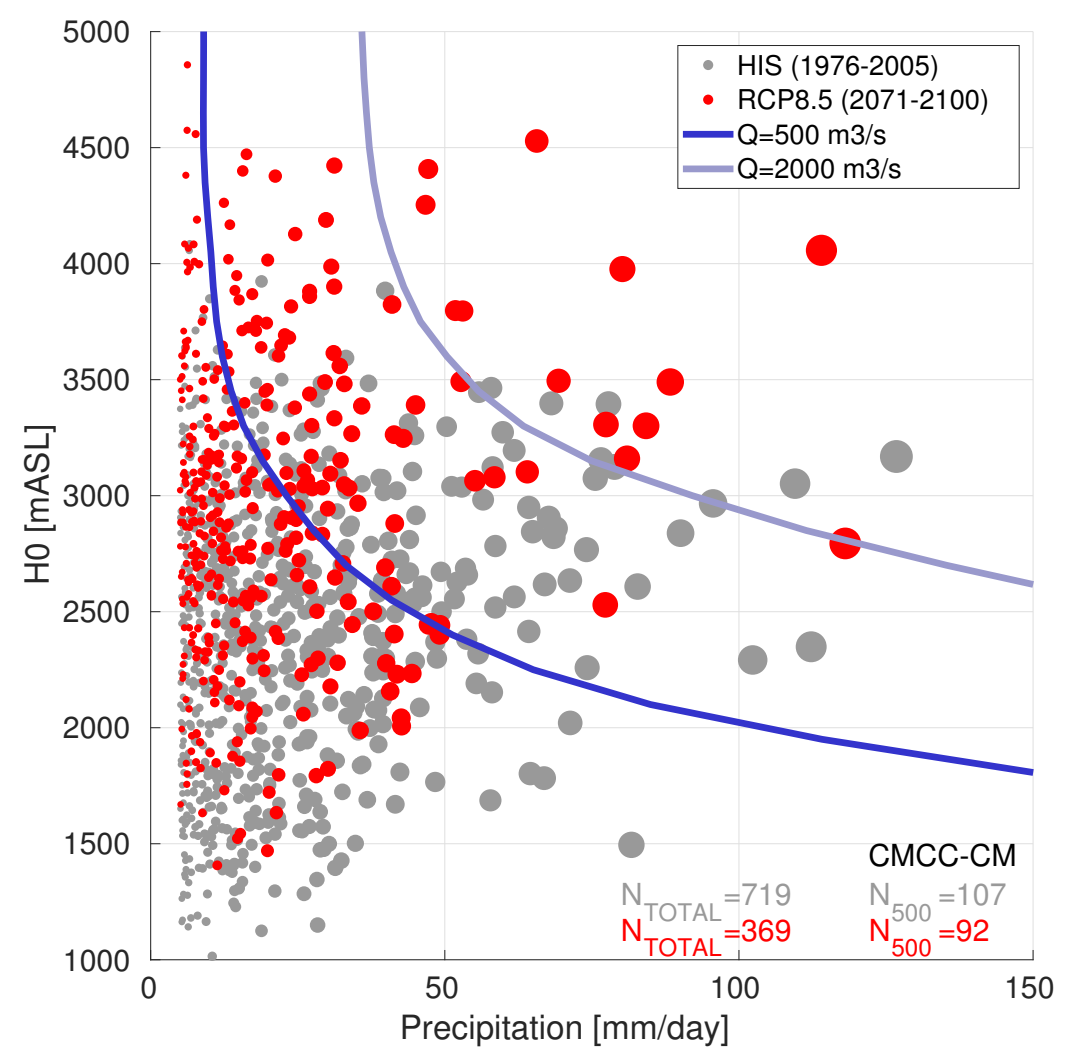

Figure 10. Scatter plot between CMCC-CM simulated daily precipitation and $H_{0}$ for wet days in Santiago (model closest point) considering the historical period (1976-2005, gray circles) and the end of century (2071-2100 under RCP8.5, red circles). The light blue line represents the combination of precipitation and $H_{0}$ values resulting in a discharge of $500 \mathrm{~m}^{3} / \mathrm{s}\left(2000 \mathrm{~m}^{3} / \mathrm{s}\right)$ in at the outlet of the upper Maipo river basin using the simplest hydrological model (Section 4.3). The number of total rainy days $\left(N_{\text {total }}\right)$ and those resulting in more than $500 \mathrm{~m}^{3} / \mathrm{s}\left(N_{500}\right)$ are shown.

The projected increase in $H_{0}$ during wet days also implies a reduced amount of water stored in the Andean snowpack that forms every winter and releases fresh water during spring/summer when this resource is most needed for agriculture and other uses in central Chile [41]. As before, we provide a rough estimate of these changes here by considering the partition between liquid and solid precipitation during winter in the Maipo river basin. For each storm, the liquid and solid volumes were calculated by multiplying the basin mean daily precipitation for the pluvial and snow areas, defined by the part of the basin below or above the freezing level, respectively. We then added all those volumes during the present (1979-2005) and future (2070-2100, under RCP8.5) periods. Solid precipitation (forming the snow pack) accounts for about $75 \%$ of the total in current climate but such contribution decrease to $57 \%$ in the far future. The total precipitation over the Maipo River basin also decreases by about 35\% (relative to present day), considering the CMCC-CM model results [37]; that figure that is in line with multimodel estimates [46]. The combined effects of warmer storms and less precipitation thus result in future (end of the century, RCP8.5) winter snow accumulation halving present climate values, ensuing a dramatic decrease in summer-fall river flow, an effect documented in other basins in central Chile by Vicuña et al. [47].

\section{Conclusions}

The distribution of $H_{0}$ along central Chile $\left(30^{\circ}-38^{\circ} \mathrm{S}\right)$ was obtained from the CFSR reanalysis for the present climate and five climate models for the rest of the 21st century under the RCP8.5 and RCP4.5 scenarios. In this highly populated region, variations of the freezing level within precipitation 
events and between storms can produce substantial differences in the pluvial area, affecting runoff generation and the discharge of rivers draining the Andes cordillera.

Relative to present day conditions, the mean $H_{0}$ in the future (RCP8.5) would be approximately $400 \mathrm{~m}$ higher for days with precipitation and $600 \mathrm{~m}$ for days without precipitation. In general, we found a progressive increase of the $H_{0}$ distribution while preserving its shape. Toward the end of the century, the mean value under wet conditions is close to or higher than the upper quartile of the $H_{0}$ distribution in the current climate, and the increase in $H_{0}$ seems to be slightly greater in the north. By the end of the century, however, the mean freezing level during wet days could be several hundred meters above the top of the southern Andes, so snowfall will likely become quite uncommon even over the highest terrain with detrimental impact for the water availability during the summer months. The more benign RCP4.5 scenario also results in a shift of the $H_{0}$ distribution toward higher values but with an amplitude about half of its RCP8.5 counterpart.

Regarding the occurrence of particularly warm storms, $H_{0}$ values that currently occur in only $5 \%$ of the days with precipitation ( $H_{0}>3300 \mathrm{~m}$ ASL) might be concurrent with nearly $25 \%(10 \%)$ of the future winter storms throughout central Chile under RCP8.5 (RCP4.5). The projected changes in $H_{0}$ translate into an increase in the pluvial area and, therefore, in the volume of water available for all the basins of central Chile during storms, except in the southernmost basins where the current freezing level is generally above the Andes ridge, at the expense of the water stored in the seasonal snowpack. The basins most affected would be those around $34^{\circ} \mathrm{S}$. The upper Maipo River, draining just to the south of the city of Santiago, might experience an increase in its pluvial area by a factor 4 to 5 times the pluvial area during future warm storms relative to mean current conditions. Keep in mind that our inferences are rough estimates of the hydrological response to changing freezing level and contingent to the negative RCP8.5 climate scenario. In this condition, even moderate daily precipitation could increase the river flow to levels that are considered hazardous for central Chile. Thus, even under the prospect of drying along central Chile, warmer winter storms in the future possess a substantial risk of landslides, flashfloods and widespread flooding along the foothills of the subtropical Andes, calling for more comprehensive studies in this subject.

Author Contributions: Conceptualization, P.M. and R.D.G.; data curation, P.M.; formal analysis, P.M. and R.D.G.; funding acquisition, P.M. and R.D.G.; methodology, P.M. and R.D.G.; resources, R.D.G.; writing-original draft, P.M. and R.D.G.; writing - review and editing, P.M. and R.D.G. All authors have read and agreed to the published version of the manuscript.

Funding: This work was funded by the National Agency for Research and Development (ANID)/PFCHA/ MAGÍSTER NACIONAL/2017-22170369. The APC was funded by the Center for Climate and Resilience Research (CR2, CONICYT/FONDAP/15110009).

Acknowledgments: We thank the Center for Climate and Resilience Research (CR2, CONICYT/ FONDAP /15110009) for its support.

Conflicts of Interest: The authors declare no conflict of interest.

\section{References}

1. Hobbs, P.V.; Easter, R.C.; Fraser, A.B. A theoretical study of the flow of air and fallout of solid precipitation over mountainous terrain: Part II. Microphysics. J. Atmos. Sci. 1973, 30, 813-823. [CrossRef]

2. White, A.B.; Gottas, D.J.; Strem, E.T.; Ralph, F.M.; Neiman, P.J. An automated brightband height detection algorithm for use with Doppler radar spectral moments. J. Atmos. Ocean. Technol. 2002, 19, 687-697. [CrossRef]

3. Fabry, F.; Zawadzki, I. Long-term radar observations of the melting layer of precipitation and their interpretation. J. Atmos. Sci. 1995, 52, 838-851. [CrossRef]

4. Lundquist, J.D.; Neiman, P.J.; Martner, B.; White, A.B.; Gottas, D.J.; Ralph, F.M. Rain versus snow in the Sierra Nevada, California: Comparing Doppler profiling radar and surface observations of melting level. J. Hydrometeorol. 2008, 9, 194-211. [CrossRef] 
5. Cui, G.; Bales, R.; Rice, R.; Anderson, M.; Avanzi, F.; Hartsough, P.; Conklin, M. Detecting Rain-SnowTransition Elevations in Mountain Basins Using Wireless Sensor Networks. J. Hydrometeorol. 2020, 21, 2061-2081. [CrossRef]

6. Medina, S.; Smull, B.F.; Houze, R.A., Jr.; Steiner, M. Cross-barrier flow during orographic precipitation events: Results from MAP and IMPROVE. J. Atmos. Sci. 2005, 62, 3580-3598. [CrossRef]

7. Minder, J.R.; Durran, D.R.; Roe, G.H. Mesoscale controls on the mountainside snow line. J. Atmos. Sci. 2011, 68, 2107-2127. [CrossRef]

8. Marwitz, J.D. Deep orographic storms over the Sierra Nevada. Part I: Thermodynamic and kinematic structure. J. Atmos. Sci. 1987, 44, 159-173. [CrossRef]

9. Garreaud, R. Warm winter storms in Central Chile. J. Hydrometeorol. 2013, 14, 1515-1534. [CrossRef]

10. Ibañez, M.; Gironás, J.; Oberli, C.; Chadwick, C.; Garreaud, R.D. Daily and seasonal variation of the surface temperature lapse rate and $0^{\circ} \mathrm{C}$ isotherm height in the western subtropical Andes. Int. J. Climatol. 2020. [CrossRef]

11. Sumargo, E.; Cannon, F.; Ralph, F.M.; Henn, B. Freezing level forecast error can consume reservoir flood control storage: Potentials for Lake Oroville and New Bullards Bar reservoirs in California. Water Resour. Res. 2020, 56, e2020WR027072. [CrossRef]

12. Fehlmann, M.; Gascón, E.; Rohrer, M.; Schwarb, M.; Stoffel, M. Estimating the snowfall limit in alpine and pre-alpine valleys: A local evaluation of operational approaches. Atmos. Res. 2018, 204, 136-148. [CrossRef]

13. Schauwecker, S.; Rohrer, M.; Huggel, C.; Endries, J.; Montoya, N.; Neukom, R.; Perry, B.; Salzmann, N.; Schwarb, M.; Suarez, W. The freezing level in the tropical Andes, Peru: An indicator for present and future glacier extents. J. Geophys. Res. Atmos. 2017, 122, 5172-5189. [CrossRef]

14. Garreaud, R.; Rutllant, J. Análisis meteorológico de los aluviones de Antofagasta y Santiago de Chile en el periodo 1991-1993. Atmósfera 1996, 9, 251-271.

15. Liu, A.; Mooney, C.; Szeto, K.; Thériault, J.; Kochtubajda, B.; Stewart, R.; Boodoo, S.; Goodson, R.; Li, Y.; Pomeroy, J. The June 2013 Alberta catastrophic flooding event: Part 1—Climatological aspects and hydrometeorological features. Hydrol. Process. 2016, 30, 4899-4916. [CrossRef]

16. Cohen, J.; Ye, H.; Jones, J. Trends and variability in rain-on-snow events. Geophys. Res. Lett. 2015, 42, 7115-7122. [CrossRef]

17. Grote, T. A synoptic climatology of rain-on-snow flooding in Mid-Atlantic region using NCEP/NCAR Re-Analysis. Phys. Geogr. 2020, 1-20. [CrossRef]

18. Musselman, K.N.; Lehner, F.; Ikeda, K.; Clark, M.P.; Prein, A.F.; Liu, C.; Barlage, M.; Rasmussen, R. Projected increases and shifts in rain-on-snow flood risk over western North America. Nat. Clim. Chang. 2018, 8, 808-812. [CrossRef]

19. Barnett, T.P.; Adam, J.C.; Lettenmaier, D.P. Potential impacts of a warming climate on water availability in snow-dominated regions. Nature 2005, 438, 303. [CrossRef]

20. Hatchett, B.J.; Daudert, B.; Garner, C.B.; Oakley, N.S.; Putnam, A.E.; White, A.B. Winter snow level rise in the northern Sierra Nevada from 2008 to 2017. Water 2017, 9, 899. [CrossRef]

21. Sepúlveda, S.A.; Padilla, C. Rain-induced debris and mudflow triggering factors assessment in the Santiago cordilleran foothills, Central Chile. Nat. Hazards 2008, 47, 201-215. [CrossRef]

22. Poveda, G.; Espinoza, J.C.; Zuluaga, M.D.; Solman, S.A.; Garreaud Salazar, R.; van Oevelen, P.J. High impact weather events in the Andes. Front. Earth Sci. 2020. [CrossRef]

23. Viale, M.; Garreaud, R. Orographic effects of the subtropical and extratropical Andes on upwind precipitating clouds. J. Geophys. Res. Atmos. 2015, 120, 4962-4974. [CrossRef]

24. Falvey, M.; Garreaud, R. Wintertime precipitation episodes in central Chile: Associated meteorological conditions and orographic influences. J. Hydrometeorol. 2007, 8, 171-193. [CrossRef]

25. Viale, M.; Valenzuela, R.; Garreaud, R.D.; Ralph, F.M. Impacts of atmospheric rivers on precipitation in southern South America. J. Hydrometeorol. 2018, 19, 1671-1687. [CrossRef]

26. Valenzuela, R.A.; Garreaud, R.D. Extreme daily rainfall in central-southern Chile and its relationship with low-level horizontal water vapor fluxes. J. Hydrometeorol. 2019, 20, 1829-1850. [CrossRef]

27. Cortés, G.; Vargas, X.; McPhee, J. Climatic sensitivity of streamflow timing in the extratropical western Andes Cordillera. J. Hydrol. 2011, 405, 93-109. [CrossRef]

28. Rojas, O.; Mardones, M.; Arumí, J.L.; Aguayo, M. Una revisión de inundaciones fluviales en Chile, período 1574-2012: Causas, recurrencia y efectos geográficos. Rev. Geogr. Norte Gd. 2014, 177-192. [CrossRef] 
29. Ayala, L.; López, A.; Tamburrino, A.; Vera, G. Aspectos hidrometeorológicos e hidrodinámicos de algunos eventos aluvionales recientes en Chile. XVI Congr. Latinoam. Hidrául. 1994, 3, 39-51.

30. Sepúlveda, S.A.; Rebolledo, S.; Vargas, G. Recent catastrophic debris flows in Chile: Geological hazard, climatic relationships and human response. Quat. Int. 2006, 158, 83-95. [CrossRef]

31. González, S.; Garreaud, R. Spatial variability of near-surface temperature over the coastal mountains in southern Chile (38 S). Meteorol. Atmos. Phys. 2019, 131, 89-104. [CrossRef]

32. National Geophysical Data Center. 2-minute Gridded Global Relief Data (ETOPO2) v2. National Geophysical Data Center, NOAA. Available online: https:/ / www.ngdc.noaa.gov/mgg/global/etopo2.html (accessed on 25 May 2019).

33. Alvarez-Garreton, C.; Mendoza, P.A.; Boisier, J.P.; Addor, N.; Galleguillos, M.; Zambrano-Bigiarini, M.; Lara, A.; Cortes, G.; Garreaud, R.; McPhee, J.; et al. The CAMELS-CL dataset: catchment attributes and meteorology for large sample studies-Chile dataset. Hydrol. Earth Syst. Sci. 2018, 22, 5817-5846. [CrossRef]

34. Saha, S.; Moorthi, S.; Pan, H.L.; Wu, X.; Wang, J.; Nadiga, S.; Tripp, P.; Kistler, R.; Woollen, J.; Behringer, D.; et al. The NCEP climate forecast system reanalysis. Bull. Am. Meteorol. Soc. 2010, 91, 1015-1058. [CrossRef]

35. Taylor, K.E.; Stouffer, R.J.; Meehl, G.A. An overview of CMIP5 and the experiment design. Bull. Am. Meteorol. Soc. 2012, 93, 485-498. [CrossRef]

36. Center for Climate and Resilience Research, (CR)2 (FONDAP 15110009). Regional Climate Simulations. Available online: http:/ / simulaciones.cr2.cl/ (accessed on 15 May 2019).

37. Mardones Bascuñan, P.B. Impactos del Cambio Climático en la Altura de la Isoterma $0{ }^{\circ} \mathrm{C}$ Sobre Chile Central. Master's Thesis, University of Chile, Santiago, Chile, 2019.

38. Riahi, K.; Rao, S.; Krey, V.; Cho, C.; Chirkov, V.; Fischer, G.; Kindermann, G.; Nakicenovic, N.; Rafaj, P. RCP 8.5-A scenario of comparatively high greenhouse gas emissions. Clim. Chang. 2011, 109, 33. [CrossRef]

39. Moss, R.H.; Edmonds, J.A.; Hibbard, K.A.; Manning, M.R.; Rose, S.K.; Van Vuuren, D.P.; Carter, T.R.; Emori, S.; Kainuma, M.; Kram, T.; et al. The next generation of scenarios for climate change research and assessment. Nature 2010, 463, 747-756. [CrossRef] [PubMed]

40. Benarroch, A.; Siles, G.A.; Riera, J.M.; Pérez-Peña, S. Heights of the $0{ }^{\circ} \mathrm{C}$ Isotherm and the Bright Band in Madrid: Comparison and Variability. In Proceedings of the 2020 14th European Conference on Antennas and Propagation (EuCAP), Copenhagen, Denmark, 15-20 March 2020; pp. 1-5.

41. Masiokas, M.H.; Villalba, R.; Luckman, B.H.; Le Quesne, C.; Aravena, J.C. Snowpack variations in the central Andes of Argentina and Chile, 1951-2005: Large-scale atmospheric influences and implications for water resources in the region. J. Clim. 2006, 19, 6334-6352. [CrossRef]

42. Lenderink, G.; Buishand, A.; Van Deursen, W. Estimates of future discharges of the river Rhine using two scenario methodologies: direct versus delta approach. Hydrol. Earth Syst. Sci. 2007, 11, 1145-1159. [CrossRef]

43. Ekström, M.; Jones, P.; Fowler, H.; Lenderink, G.; Buishand, T.; Conway, D. Regional climate model data used within the SWURVE project 1: projected changes in seasonal patterns and estimation of PET. Hydrol. Earth Syst. Sci. 2007, 11, 1069-1083. [CrossRef]

44. Zazulie, N.; Rusticucci, M.; Raga, G.B. Regional climate of the Subtropical Central Andes using high-resolution CMIP5 models. Part II: future projections for the twenty-first century. Clim. Dyn. 2018, 51, 2913-2925. [CrossRef]

45. Bustos Cavada, D. Cambio climático y eventos de emergencia en el suministro de agua potable en el gran Santiago. Bachelor's Thesis, University of Chile, Santiago, Chile, 2011.

46. Bozkurt, D.; Rojas, M.; Boisier, J.P.; Valdivieso, J. Projected hydroclimate changes over Andean basins in central Chile from downscaled CMIP5 models under the low and high emission scenarios. Clim. Chang. 2018, 150, 131-147. [CrossRef]

47. Vicuña, S.; Garreaud, R.D.; McPhee, J. Climate change impacts on the hydrology of a snowmelt driven basin in semiarid Chile. Clim. Chang. 2011, 105, 469-488. [CrossRef]

Publisher's Note: MDPI stays neutral with regard to jurisdictional claims in published maps and institutional affiliations. 